Arab World English Journal (AWEJ) 2 ${ }^{\text {nd }}$ Special Issue on Covid 19 Challenges January 2022 DOI: https://dx.doi.org/10.24093/awej/covid2.23

\title{
The Use of Blackboard in the Practice of English-Speaking Skills among Saudi EFL Learners during COVID-19
}

\author{
Emran Ismail Al-Oqaily
}

Language Academy, Faculty of Social Sciences and Humanities Universiti Teknologi Malaysia, Johor, Malaysia

Corresponding Author: oqaily82@gmail.com

\author{
Abdul Rahim Hj Salam \\ Language Academy, Faculty of Social Sciences and Humanities \\ Universiti Teknologi Malaysia, Johor, Malaysia

\section{Dr. Kew Si Na} \\ Language Academy, Faculty of Social Sciences and Humanities \\ Universiti Teknologi Malaysia, Johor, Malaysia
}

Received:12/6/2021

Accepted: 1/ 11/2022

Published: $1 / 24 / 2022$

\section{Abstract}

The current coronavirus (COVID-19) epidemic caused a temporary halt to educational activities around the world. The abrupt and fast shift from regular face-to-face learning to fully online learning altered the students' impressions toward the Blackboard application and its use. It is important to have an in-depth analysis of the effectiveness of using the blackboard platform in developing students' skills. The current study included a review of both quantitative and qualitative papers according to their relevance to the Saudi context to get a clearer image about the use of blackboard in building up Saudi EFL learners speaking skills. The purpose of this study is to address and review the studies that investigate students' perceptions of the Blackboard program as a mere tool of learning English courses in Preparatory Year, as well as the impact of those perceptions on students' use of Blackboard. This work underlines previous literature associated with blackboard as a platform in the practice of speaking skills in the English language among Saudi English as Foreign Language (EFL) Learners. It is meant to provide an overview of how Blackboard computer and internet-based virtual class (CIBVC) is used to overcome Saudi EFL learners' difficulties in English-speaking skills and describes their speaking ability from the perspectives of accuracy, fluency, and Anxiety. This work suggests that the students' earlier knowledge of online learning via Blackboard has a positive impact on their perceptions. It also contributed to online learning of English language speaking skills and the learning via the online learning platforms' research field during the outbreak of COVID-19 pandemic.

Keywords: blackboard, speaking skills, fluency, accuracy, managing anxiety, covid-19, online learning, Perception

Cite as: Al-Oqaily, E. I., \& Salam, A. R. (2022). The Use of Blackboard in the Practice of EnglishSpeaking Skills among Saudi EFL Learners during COVID-19. Arab World English Journal (AWEJ) $2^{\text {nd }}$ Special Issue on Covid 19 Challenges (2) 342 -355.

DOI: https://dx.doi.org/10.24093/awej/covid2.23 


\section{Introduction}

The students' perceptions towards the use of management systems such as Blackboard are mainly allied with a student's effective utilization of these tools (Santandreu et al., 2010). As a result, students must be prepared to recognize the move from conventional to online learning, and the relevance of Blackboard and other e-learning tools as the only alternative for conventional instruction during crisis times should be highlighted to them (Fageeh, 2011). In education, English has become the global language that is used for communication as it is spoken by more than a third of the world's population. Genc (2007) revealed that, in any language learning, there are four main skills that should be acquired to handle communication. When a child grew up starting to listen in the first stage, then starting to speak after acquiring the basics, later starting to read and write as entering schools or be taught to, these skills are the four language skills.

Learning the English language involves those four skills. Speaking is a basic skill that needs having communicative competence, comprehension, fluency, accuracy, vocabulary, grammar and pronunciation, and gesture improving, to develop good communication. All of these aspects are necessary to measure students' competence in speaking employing proper procedure. Brown (1994) asserted that speaking skill is crucial in the production of verbal language. However, language is a tool of communication rather than an utterance. Speaking skills appear when two or more people communicate to maintain a social and intimate relationship between them. Widdowson (1994) argued that speaking is an interactive dynamic skill that comes in form of verbal output. It is the ability of an individual to interact verbally with others. Consequently, speaking is a productive skill that undergoes an interactive process of creating meaning that entails producing, obtaining, and processing information. By means of speaking with others, information can be obtained about what is going on in the world.

Unluckily, speaking skill is almost neglected or not taught in the proper way in the best cases (Alhmadi, 2014). Corresponding to the related literature, this happened as a result of less trained teachers who do not know how to teach their students speaking skills, which results in their ignorance of its value. Different countries have different languages. It is impossible for people from around the world to communicate with each other without a common language. The term lingua franca is used to describe such a common language, defined by Jenkins (2011, p.1) as "contact languages used among individuals who do not share a first language", which knocks the door toward the importance of English as an international language.

Speaking is a key element for communication and interaction between people in the social context. By thinking about what a competent speaker does, which speaking approaches to be applied inside the classroom, and what are the demands learners require, teachers can assist the students in acquiring and developing their speaking ability and competency. Speaking is a routine activity that should be kept and developed daily. Moreover, applied linguistic presents a set of explanations of spoken language, speaking as a collaborative activity, and speaking as an interpersonal and activity based on situation (Thornbury, 2005). In a research review, speaking is considered a crucial part of learners' daily lives which entails an interactive process of sending and receiving speech. However, speaking is a collaborative process of meaning construction that comprises the production, getting the message, and handling it. Altogether, researchers assist evaluation of the process with a clear representation and interpretation of the importance of 
Arab World English Journal (AWEJ) 2nd Special Issue on Covid 19 Challenges January 2022

The Use of Blackboard in the Practice of English-Speaking Skills

Al-Oqaily \& Salam

speaking skills in a language and then having a task-based construction of practices and assessment principles (Brown, 1994).

This work underlines related studies associated with blackboard as a platform in the practice of speaking skills in the English language among Saudi English as Foreign Language (EFL) Learners. At First, it has provided an overview of Blackboard computer and internet-based virtual class (CIBVC). Then, it introduces a brief of the theoretical keystones of this study. After that, it reviews Saudi EFL learners' difficulties in English-speaking skills and describes their speaking ability from the perspectives of accuracy, fluency, and Anxiety. Finally, speaking practices in the class are demonstrated relating to the learner-instructor interaction.

\section{Literature Review}

The issue of using Blackboard as a language teaching and learning tool in the Arab world is being increasingly studied in recent years due to the impact it can carry on the achievement and performance of learning a foreign language. Not much work has been performed in the area of fully online learning. As the main concern of Social Cultural Theory is to focus on how adults and peers influence individual learning. This study is meant to contribute to the literature in the field of social-cultural theory.

The COVID-19 epidemic posed a challenge to colleges all around the world, forcing governments to switch from conventional learning to online mode of learning (Dhawan, 2020). Accessibility, cost, tractability, learning sources, quality management, and readiness were all issues that universities had to deal with. ( Sun et al., 2020) emphasized the significance of a quality management program and ongoing improvement for a successful online learning as well as having the whole world to be prepared for any interruption. According to Dhawan (2020), the World Economic Forum (WEF) emphasized that individuals must be prepared for difficult situations, as the COVID 19 epidemic pushed many of them to rethink their perspectives on schooling. Having New Zealand as an example, where the seismic activity occurred and educationalists attempted to limit the constraints, Ayebi-Arthur (2017) proposed a solid technological infrastructure as a requirement for learning via online platforms. To cater for challenging situations, the educational organizations equipped a comprehensive guide for students and tutors to alleviate the case and aided everyone to get to online Learning through Management Systems (LMSs) platforms (Yen 2020). Universities in Saudi Arabia implemented the Blackboard platform as an online learning system, which had all topographies and accommodations to provide a similar context like real classrooms (Dgebuadze et al., 2020).

\section{Blackboard Use in Learning of Speaking Skills in the English Language}

Technology-based learning is a term with rapid change related to the notion of technology which is changeable and going in a tremendous development and widespread possibilities in the field of learning as many attempts were applied; to find the open-source information provider which is the internet. Technology-based Learning entails the use of computer-mediated learning and online learning and it is commonly addressed with Educational Technology and ComputerAssisted Language Learning (CALL) in short (Sharpe \& Oliver, 2007). Regardless of the given names, all these tools focus on the implementation of technology in teaching and learning. Technology-based classroom in language teaching has been proven to be effective and strengthen engagement through putting learners in front of audiences from all over the world to 
Arab World English Journal (AWEJ) 2nd Special Issue on Covid 19 Challenges January 2022

The Use of Blackboard in the Practice of English-Speaking Skills

Al-Oqaily \& Salam

improve collaborative learning practice which prepares them to be competent users of the target language (Altun, 2015).

There has been a lot of orientation on the way to computerized programs' use in teaching and learning foreign languages. Consequently, there is a growing utilization of CALL systems in educational institutions. Teaching via technology is one of the most growing areas in this field. Technology appliances that have come into schools in 1951s in the states are gradually growing all over the globe. Furthermore, as computers developed to be faster, more effective, more convenient, functional, less expensive, as well storing and processing much more data (Gunduz $\&$ Hursen, 2015). Moreover, computer-assisted tools are enormously developed, and they enrich the language learning environment through the starring role of computers and gives it more importance, which results in a better teaching and learning process (Raji, 2019).

Hubbard and Levy (2016) considered that a real effort in improving learning and teaching language using computers started by the 1960s, yet it remained ineffective and inappropriate till the 1980s when an increasing use of microcomputers started to spark that groups of experts who started establishing professional groups and a recognized field identification occurred. Despite the fact that the initial launch of computer-assisted language learning to develop learning language has not been touched, the following decades have seen an interesting range of growth. This is due to the fact that gained experiences from practice and research, and the fast and progressive change in the field of technology in language learning. (Sadeghi et al. (2014) claimed that the tutors are enthusiastic concerning the notion of implementing technology for purposes of teaching in many educational institutions. Yet, the process of executing innovative tools and administering revolutionary shifts is still unreachable and challenging. A considerable effort is required for the successful use of new technologies especially at the part of involved administrative people to fully implement technology-based instruction.

Innovative ways have been illuminated in English education by incorporating the advancement of internet technology into language learning processes (Celik et al., 2013). For instance, fully online learning and blended or hybrid learning have been adopted to supplement learners' language learning in addition to having classes in a traditional classroom. Here, having class in a traditional classroom means that there is a teacher and some students in one room engaging in teaching and learning. In order to give a straightforward explanation of the former two different learning environments, fully online learning is conducted entirely through the internet; blended learning is a "combination of face-to-face and online teaching and learning" ( Boulton et al. (2008) as cited in FERSAOUI, 2016, p.47). It can be concluded that technology increases the diversity of language learning environment.

In the technological context and its interrelated sciences, a review of the teaching approaches is needed to motivate learners to use collaborative learning in pairs and in groups speaking practices, and writing tasks (Qizi, 2021). As for universities, the potentials of using technologybased instruction and learning is mature enough to cater for the previously stated complications, the application of Blackboard Computer and Internet-Based Virtual Class (CIBVC) in teaching and learning speaking skills should be of great interest (Al Ajlan, 2021). Colorado and Eberle (2012) made a classification of the development of distance education in the historical context, CIBVC is the fifth and the latest generation. The arrival of CIBVC has realized the possibility of 
Arab World English Journal (AWEJ) 2nd Special Issue on Covid 19 Challenges January 2022

The Use of Blackboard in the Practice of English-Speaking Skills

Al-Oqaily \& Salam

creating an authentic and interactive spoken English teaching and learning environment online. The mode of Blackboard communication is of particular interest since it builds up an individualized and private class setting in stark contrast to a large class size of a specific Saudi EFL class (Alsuhaibani 2021; Moh'd Amer Hawari \& Huwari 2021; Ta'amneh, 2021).

\section{Social Cultural Theory and Speaking Skills in the English Language}

In Sociocultural theory, language learning is different from language development (Lantolf, 2007). Learning leads and shapes the development and be able to encourage qualitative hormonal shifts (Lantolf \& Poehner, 2014). Therefore, learning a language directs to language advancement on the student as a gradual and ongoing process. It is not a straightforward, causal process, but meaningful social interactions in intentionally designed language-learning environments (Norton \& Hathaway, 2009).

Throughout the online learning environment, learners can learn from each other in the classroom and outside the classroom. This collaborative environment creates a collective Zone of Proximal Development (ZPD) that connects individual ZPDs with different abilities to enable learners to take advantage of other peers' knowledge, feelings, and benefits (De Marsico et al., 2013). This collective ZPD contributes to others' learning, accommodates diverse membership, and nurtures multiple perspectives' authentic expression (Gunawardena et al., 2018).

Recent studies implement Sociocultural theory as an umbrella for all the underpinning theories where they are rooted and linked together to interpret and elicit learners' speaking skills development. The collaborative efforts made by the tutor and the learner during the learning process when they speak with each other by using English via blackboard computer and internetbased virtual classroom. Some works tend to draw on Sociocultural theory, aiming at investigating how Arab EFL learners in a CIBVC blackboard speaking class scaffolded each other while carrying out collaborative learning tasks to reach their ZPD.

The findings of Dharmawardene (2019) show that the blended mode can be successfully used to help business professionals improve their English-speaking skills, which supports Vygotsky's (1978) Social Cultural theory, which views learning as a complex phenomenon best accomplished in a collaborative environment. The authors claim that the study's findings will be useful to higher education administrators, such as those at universities, who want to start or continue offering blended Business English courses. Furthermore, future adult students who seek to improve their English-speaking skills by taking a blended English course will profit greatly from the outcomes of this study. To compare the outcomes of alternative pedagogies, the same study can be reproduced in a different location at a different time or for different subjects. The University of Colombo in Sri Lanka generated the raw data.

\section{Blackboard as a Key Learning Platform During COVID-19 Period}

Blackboard is an online learning management software designed to boost the teaching and learning process. The teacher can add learning materials such as audios, videos, PowerPoint, animation, links, and so forth to Blackboard course content. Moreover, the instructor can ask students to do online assignments, quizzes, and surveys. Many features are included in the design of Blackboard as it provides the opportunity to create discussion forums, portfolios, wikis, blogs, and groups for student-student and student-teacher interaction. Tracking and assessing students 
are also available alongside other features such as SafeAssign, enhanced cloud profile, student preview content editor, group management, grading enhancements, calendar, Blackboard drive, social learning, collaborate integration, dynamic content, retention centre, course enrolments, and active collaboration.

Blackboard applications have the potential to revolutionize learners' perception to learn and teachers' way of teaching (Hakim, 2020). To present a collaborative mode of learning; it should be customized to reach students' special demands and inspire them of the process of choosing and developing online resources that adjust practices in traditional teaching and learning (Huang, 2020). However, like any technology, Blackboard cannot offer successful education itself; success depends on how it is used, planned, and supported by different strategies.

Regarding Moore and Kearsley's (2011) classification of the development of distance education in the historical context, CIBVC is the fifth and the latest generation. The arrival of CIBVC has realized the possibility of creating an authentic and interactive spoken English teaching and learning environment online. The mode of Blackboard communication is of particular interest since it builds up an individualized and private class setting in stark contrast to a large class size of conventional Saudi EFL class. Because of the spread of COVID-19, many countries worldwide have fully transferred to virtual education. The importance, of having students prepared for this type of instruction, has been the major concern in places where learners are of no experience in using online platforms.

In Saudi Arabia, universities generally administer to use Blackboard for delivering online learning courses. However, a limited number of studies were handled in EFL learning to investigate and assess both synchronous and asynchronous aspects of Blackboard. This reveals that Blackboard's usage for learning EFL at Saudi universities calls for more in-depth research (Al-Nofaie, 2020). In her study, the author reveals that online learning provided an opportunity for covert learners to express their thoughts more easily. This was obvious in the discussion forums. Students share their opinions and related proof to facilitate active learning engagement. Interestingly, it was noticed that the forums were helpful for covert learners who used to hesitate when taking part in a face-to-face classes.

Ali (2017) investigated the use of the Blackboard platform in teaching and learning and evaluated its influence on motivating Saudi English students. The author investigated the use of Blackboard on the motivation of English students from their viewpoint and seeks to ascertain whether students confront problems that influence their motivation. The study noticed that using Blackboard encourages hard work and promises a better learning method than traditional. It also found that students think that Blackboard is a motivating factor. Mohsen and Shafeeq (2014) tend to investigate teachers' perceptions of Blackboard applications in teaching English as a foreign language. The data were gathered using a survey and an interview with EFL university teachers from Saudi Arabia. The results show that EFL teachers' perception, about using the Blackboard platform in the teaching and learning process, was positive. The majority of the teachers mentioned that they have effectively work on the platform. The study verifies that Blackboard is straightforward and easy-going program that can be used to manage constructive e-learning courses that aided a successful teaching process. 
Moreover, Ali (2017) carried out a multi-method study of students' perception of Blackboard as a tool of online learning. The study has highlighted the positive attitudes of EFL learners towards using Blackboard and related their attitudes to their high motivation levels. The work reviews Blackboard's role in the motivation of students and aims to determine whether learners encounter problems that affect their enthusiasm. The study's findings reveal that using Blackboard enables and motivates students to achieve learning goals and so learn better than regular methods of understanding with the belief that Blackboard is a motivating factor.

Another study by Al-Rubaat (2017), at Al Jouf University in Saudi Arabia, concentrated on Blackboard's use by EFL learners. The work shows that learners agree that using Blackboard can expand the scope of their learning ability. However, many students were nonaligned with the use of Blackboard learning over face-to-face learning. Moreover, many students were neutral about the effectiveness of Blackboard as an engaging learning environment. Mahasneh et al. (2017) considered this neutrality to be related to the learners' insufficient awareness of Blackboard and its benefits. Another study by Al-Mubireek (2019), compared students' use of Blackboard versus the use of Oxford IQ. Students showed positive attitudes towards online learning systems. Yet, the students in Al-Mubireek's research were accessed online learning media only for two weekly hours.

It is worth mentioning here that comparing both synchronous and asynchronous aspects of Blackboard in the Saudi context was not taken into consideration in these studies. Similarly, all these studies use online learning not to replace but rather to aid regular face-to-face learning (i.e., blended learning). In such cases, limited time is given to learners in online learning. Accordingly, this limited use may have led to the students' more positive perception of online learning.

\section{The necessity of Using Blackboard in Learning During COVID-19 Period}

Roughly, education all over the world was shifted to be online due to the COVID-19 pandemic. Therefore, teachers and learners were left with no other options or alternatives but to use online learning. Corresponding to what happened in the rest of the world, Saudi Arabia declared the quarantine in early March 2020, without any proper preparation, the Ministry of Education was vigilant to keep all educational institutions including schools and universities on track with their educational plans by shifting to online teaching and assessment (Al-Nofaie, 2020).

Aoumeur (2017) find out that large class size harmed the quality of EFL teaching and learning. Students complained about it as they did not have enough opportunities to express themselves, while the teachers complained that the students passively engaged in class. Although the findings seem contradictory, it reflects a common phenomenon in a large size EFL class. The phenomenon is that class duration limits teacher-student interaction. In particular, if the teacher does not find a way to get all the students involved in-class participation, there are only a minority of students actively participating in the discussion. Some students have ideas in mind, but they do not take the initiative to express themselves. Some students do not try to participate in the discussions if they do not have to. It has been proven that large classes cause a negative effect on EFL teaching and unsatisfactory learning outcomes. 
By means of Blackboard, both teachers and learners can switch their traditional ways of teaching and learning to an interactive virtual environment (Mohsen \& Shafeeq 2014). The Blackboard represents an extremely collaborative and feasible learning environment that can be personalized to meet the needs of the students (Alharbi, 2015). Researchers dealt with numerous characteristics and tools of the Blackboard platform as a learning system. According to Alamer (2020), Blackboard is recognized to be easy to use, ubiquitous and accessible. Blackboard provided teachers with the complete facilities to accomplish the curriculum goals and follow the track of students' activities Gördeslioğlu and Yüzer (2019). According to Narwani and Arif (2008), Blackboard was taken as the finest learning management system for teaching and learning, content administration, and end-products assessment. As a result, Blackboard was broadly employed due to the fact of several features and humble use (Narwani \& Arif 2008; Al Refaai et al., 2013). Furthermore, based on Mohsen and Shafeeq (2014), the majority of the teachers considered Blackboard as a user-friendly platform that assisted instructors and students to achieve the overall success of the process for teaching and learning. The specifications of enhanced communication, obtainability, quick feedback, skill-building, and tracking progress described Blackboard as the best of all LMSs presentations and support students with a better opportunity to interact with teachers (Whitmer, 2016). As a result of these topographies, Blackboard has introduced a new integrated face-to-face learning environment.

\section{The Importance of Computer and Internet-Based Virtual Class}

Having CIBVC become a necessity for teaching and learning in such situations. In Saudi Arabia, almost all the higher education organizations have used Blackboard with a developed pedagogy that fits teaching online before the emergence of COVID-19. Via implementing Blackboard computing initiatives, (Penuel et al., 2006) paid attention to the implementation of Blackboard computing initiatives in schools reviewed four goals of this process on the part of students. Firstly, helping students to improve their academic achievements using technology integration. Secondly, offering equal access to digital resources. Thirdly, enabling students with low chances to access the resources to get prepared for modern society's technology-saturated workplaces increases economic competitiveness. Fourthly, it expects to effect a transformation in instruction quality by introducing abundant access to the initiative's resources.

Khafaga and Shaalan (2021) explore both students' and teachers' attitudinal perceptions towards Blackboard in the learning/teaching process. participants of this study who were from five universities in KSA stressed that Blackboard enhances their language and communicative abilities. The complete shift to online learning due to covid19 using Blackboard helps students to improve their speaking and listening as they have open access to language course information. The use of chatting and group conferencing develop their communicative English skills and increase their exposure to language use.

The main contributing factor of online learning is that it enhances students' engagement in learning. Student engagement is significant because it positively influences learners' engagement, develops their learning rationale, decreases their feeling of being isolated, and enriches their accomplishment when taking classes online (Martin and Bolliger 2018). The computer is the tool commonly used for connecting the internet. Student engagement is primarily boosted by using computers with an internet connection since it provides the student with more opportunities to take an active role in learning and teaching development. It is significant for 
language learning especially speaking skill which develops with good practice. "Prospective students seek to upskill, re-train, and undertake further study," and thus, it increases "demand for flexible online offerings" (Roddy et al. 2017, p. 1).

Taking English learning as an example, in Saudi Arabia, English is not only a core subject learned by full-time students at different levels of schools and in higher education nowadays. A wide range of occupations in various companies in the market requires having a good command of the English language from their employees as English is used frequently at work; more and more people learn English to pursue their studies abroad, and others would like to improve their English proficiency to interact with people in English when going out of the country. In these circumstances, Blackboard CIBVC can be a good choice for their studies.

As stated by (eM Elsawy \& Ahmed, 2019), online learning makes a chance for everyone to get an education, increase communication abilities through many directions, availability of resources, enhance self-education, and overcome barriers o traditional education like time, place, working conditions. Having Blackboard CIBVC caters to English learners' different personal needs for their studies in an authentic and interactive learning context, which is expected as a promising educational mode.

\section{Speaking Practice in Blackboard Computer and Internet-Based Virtual Class}

The Blackboard Collaborate is the first language management system employed in most of the universities in Saudi Arabia during the COVID-19 pandemic as it is ubiquitous, userfriendly, and accessible. Higher educational institutions, with no exception, replace traditional in-class teaching and learning with a computer and internet-based one. This enables the integration of pedagogies and technology. Online teaching is adopted, and the use of learning management systems such as Blackboard Collaborate started to operate successfully. Khafaga and Shaalan (2021) studied EFL learners'/teachers' perceptions of using and implementing Blackboard Collaborate as a means of instruction in Saudi universities. The study shows that Blackboard can be efficient in developing the Saudi EFL teaching/learning process during COVID-19. The Blackboard-based classes make new perceptions towards emerging technologies in education.

Studying Learning Management Systems (LMSs), for instance, Blackboard, from the perceptions of students is highly connected to successful use of related tools and software on the part of students (Almekhlafy, 2020). The learners' perceptions of the use of Blackboard as a virtual learning system in the COVID-19 outbreak was unexpected. Likewise, Almekhlafy (2020) reveals that all preparatory year students, with no prior knowledge of blackboard, utilizing blackboard in learning, found it a highly encouraging system and gave positive feedback during the COVID-19 outbreak. Throughout the teaching and learning course, the teacher and the learner should actively interact to obtain a productive teaching and learning outcome. Besides, it should be guaranteed that the technology utilized to build up the interaction is user-friendly and can provide them with high quality of teaching and learning experience such as the internet status is always stable.

Although Blackboard CIBVC is yet to be broadly explored, the integration of technology helps Saudi EFL students' English learning receive positive feedback. The students perceived 
that their communication skills improved in getting involved in a web-based instructional environment, and this learning environment greatly enhanced their learning experience (Aljuaid, 2021). A report published by the Blackboard website in which it matched the use of its features with learners' achievement assumed that fewer use of Blackboard tools has likely encountered for more minor accomplishments. Consequently, a need of signifying on the use of different Blackboard features as a learning platform is demanded to guarantee the capability and practicality of Blackboard (Martin \& Whitmer, 2016). (Meyer et al. (2014), Banna et al. (2015), Tyler et al. (2015) highlight the importance of engagement for students in online learning as they believe that learners' cognitive development, as well as their ability to manage their knowledge which leads them to a high level of success, can be achieved by engagement.

\section{Conclusion}

The students' perceptions had a significant impact on their use of Blackboard as a platform for online learning during the outbreak of COVID-19. During the COVID-19 epidemic, not all preparatory year students viewed Blackboard positively in different studies. The restrictions and obstacles to utilizing Blackboard were also found to have a significant impact on students' opinions of the platform. Students' impressions of Blackboard were negatively impacted due to a lack of access and a lack of technical capabilities. Implementing Blackboard in teaching and learning can improve students' overall learning results, increase both motivation and efficiency, and empower a positive attitude towards the language skill being learned. As a result, regular and proper introduction of online learning via Blackboard is required, as well as the elimination of all flaws, to establish a more encouraged and efficient online learning setting. further research into the use of Blackboard in improving other language learning skills can be conducted.

\section{Authors the Authors:}

Emran I. Al-Oqaily. Ph.D. Candidate, Language Academy, Universiti Teknologi Malaysia. His research interest is related to the use of technology in language learning and computer mediated communication as well as language learning and language acquisition. ORCID: 0000-00022163-6417

Dr. Abdul Rahim Bin Haji Salam. Associate Professor, Language Academy. Universiti Teknologi Malaysia, His research and teachings are wide-ranging within or intersections between TESL and Technology in Language Learning. ORCID: 0000-0002-8023-1014

Dr. Kew Si Na, Senior Lecturer, Language Academy. Universiti Teknologi Malaysia, email: Her research interest is wide-ranging in Technology and Language Education (TLE), Online Teaching and Learning, Learning Analytics (LA), Teaching English as a Second Language (TESL), Technology-enhanced Language Learning (TELL), Computer-assisted language learning (CALL). ORCID: 0000-0001-6648-6806

\section{References}

Al-Mubireek, S. (2019). E-learning in the English classroom: Comparing two e-learning platforms impacting preparatory year students' language learning. CALL-EJ 20(2), 1937. 
Arab World English Journal (AWEJ) 2nd Special Issue on Covid 19 Challenges January 2022

Al-Nofaie, H. (2020). Saudi University Students' Perceptions towards Virtual Education during COVID-19 Pandemic: A Case Study of Language Learning via Blackboard. Arab World English Journal, 11(3), 4-20. https://dx.doi.org/10.24093/awej/vol11no3.1

Al-Rubaat, A. M. (2017). Difficulties in Consonant Sound Pronunciation for the Undergraduate Learners at Aljouf University, Saudi Arabia. International Journal of Linguistics, Literature and Culture, 4(3), 106-115.

Al Ajlan, A. (2021). Older refugees in Germany: what are the reasons for the difficulties in language-learning? Journal of Refugee Studies, 34(2), 2449-2465. https://doi.org/10.1093/jrs/fez056

Al Zumor, A. W. Q., Al Refaai, I. K., Eddin, E. A. B., \& Al-Rahman, F. H. A. (2013). "EFL Students' Perceptions of a Blended Learning Environment: Advantages, Limitations and Suggestions for Improvement. English Language Teaching, 6(10), 95-110.

Alamer, H. A. H. (2020). Impact of Using Blackboard on Vocabulary Acquisition: KKU Students' Perspective. Theory and Practice in Language Studies, 10(5), 598-603.

Alharbi, M. (2015). Effects of Blackboard's Discussion Boards, Blogs and Wikis on Effective Integration and Development of Literacy Skills in EFL Students. English Language Teaching, 8(6), 111-132.

Alhmadi, N. S. (2014). English speaking learning barriers in Saudi Arabia: A case study of Tibah University. Arab World English Journal 5(2),38-53.

Ali, J. K. M. (2017). Blackboard as a motivator for Saudi EFL students: A psycholinguistic study. International Journal of English Linguistics 7(5), 144-151.

Aljuaid, H. (2021). Online Learning of English Language Courses via Blackboard at Saudi Universities During COVID-19: Challenges and Difficulties, The Journal of Asia TEFL, 18(3), 780-799

Almekhlafy, S. S. A. (2020). Online learning of English language courses via blackboard at Saudi universities in the era of COVID-19: perception and use. PSU Research Review, 6(3), $\mathrm{e} 03627$.

Alsuhaibani, Z. (2021). Saudi EFL Students' Use and Perceptions of Blackboard before and during Online Learning Amid COVID-19. Arab World English Journal (AWEJ) Special Issue on CALL(7). 22-37. DOI: https://dx.doi.org/10.24093/awej/call7.2

Altun, S. (2015). The effect of cooperative learning on students' achievement and views on the science and technology course. International Electronic Journal of Elementary Education, 7(3), 451-468.

Aoumeur, H. (2017). The impact of class size on teaching and learning English as a foreign language: the case of the department of English at Abdelhamid Ibn Badis University. Arab World English Journal (AWEJ), 8. 349-361.

Ayebi-Arthur, K. (2017). E-learning, resilience and change in higher education: Helping a university cope after a natural disaster. E-learning and Digital Media, 14(5), 259-274.

Banna, J., Lin, M. F. G., Stewart, M., \& Fialkowski, M. K. (2015). Interaction matters: Strategies to promote engaged learning in an online introductory nutrition course. Journal of online learning and teaching/MERLOT, 11(2), 249-361.

Basilaia, G., et al. (2020). Replacing the classic learning form at universities as an immediate response to the COVID-19 virus infection in Georgia. International Journal for Research in Applied Science and Engineering Technology, 8(3), 101-108. 
Arab World English Journal (AWEJ) 2nd Special Issue on Covid 19 Challenges January 2022

The Use of Blackboard in the Practice of English-Speaking Skills

Al-Oqaily \& Salam

Brown, A. L. (1994). The advancement of learning. Educational researcher, 23(8), 4-12. https://doi.org/10.3102/0013189X023008004

Celik, S., Aytın, K., \& Bayram, E. (2013). Implementing cooperative learning in the language classroom: opinions of Turkish teachers of English. Procedia-Social and Behavioral Sciences 70, 1852-1859. https://doi.org/10.1016/j.sbspro.2013.01.263

Colorado, J. T., \& Eberle, J. (2012). Student demographics and success in online learning environments. EMPORIA STATE RESEARCH STUDIES, 46(1), 4-10

De Marsico, M., Sterbini, A., \& Temperini, M. (2013). A strategy to join adaptive and reputation-based social-collaborative e-learning, through the zone of proximal development. International Journal of Distance Education Technologies (IJDET), 11(3), 12-31.

Dharmawardene, R. (2019). Challenges in English Language Skill Development in Business Professionals: A Comparative Study. SRI LANKA ECONOMIC RESEARCH CONFERENCE (SLERC) 2019. Wayamba University of Sri Lanka, Kuliyapitiya, Sri Lanka.

Dhawan, S. (2020). Online learning: A panacea in the time of COVID-19 crisis. Journal of Educational Technology Systems 49(1), 5-22. https://doi.org/10.1177/0047239520934018

eM Elsawy, A., \& Ahmed, O. (2019). E-Learning using the Blackboard system in Light of the Quality of Education and Cyber security. International Journal of Current Engineering and Technology, 9(1), 49-54. https://doi.org/10.14741/ijcet/v.9.1.7

Fageeh, A. I. (2011). EFL students' readiness for e-learning: Factors influencing e-learners' acceptance of the Blackboard in a Saudi university. Jalt Call Journal, 7(1), 19-42.

FERSAOUI, I. (2016). The Future of Teacher-Learner Relationship in a Plugged Context: Case of EFL Teachers and LMD Graduate Students at the University of Oran, Université d'Oran 2 Mohamed Ben Ahmed, (Unpublished Doctoral Thesis). University of Oran 2, Algeria

Genç, B. (2007). An analysis of communication strategies employed by Turkish-speakers of English. Unpublished doctoral dissertation, Department of English Language Teaching, Çukurova University, Adana.

Gördeslioğlu, N. G., \& Yüzer, T. E. (2019). Using LMS and blended learning in designing a course to facilitate foreign language learning. KnE Social Sciences:, 10-25.

Gunawardena, C. N., Frechette, C., \& Layne, L. (2018). Culturally inclusive instructional design: A framework and guide to building online wisdom communities. Routledge.

Gunduz, N., \& Hursen, C. (2015). Constructivism in teaching and learning; Content analysis evaluation. Procedia-Social and Behavioral Sciences 191, 526-533. https://doi.org/10.1016/j.sbspro.2015.04.640

Hakim, B. M. (2020). EFL teachers' perceptions and experiences on incorporating blackboard applications in the learning process with modular system at ELI. International Journal of Innovation, Creativity and Change, 12(2), 392-405.

Huang, Q. (2020). Analysis of the Pros and Cons of Students' Online Courses during the Epidemic and the Prospects for the Development of English Online Platform in Secondary Vocational School. Education Reform and Development, 2(1), 17-21.

Hubbard, P., \& Levy, M. (2016). Theory in computer-assisted language learning research and practice. In F. Farr \& L. Murray (Eds.), The Routledge handbook of language learning and technology (pp. 24-38). New York, NY: Routledge. 
Arab World English Journal (AWEJ) 2nd Special Issue on Covid 19 Challenges January 2022

Jenkins, A. (2011). Participation in learning and wellbeing among older adults. International journal of lifelong education, 30(3), 403-420. https://doi.org/10.1080/02601370.2011.570876

Khafaga, A. F., \& Shaalan, I. E. N. A. W. (2021). Mobile learning perception in the context of COVID-19: An empirical study of saudi EFL majors. Asian EFL Journal, 336-356.

Lantolf, J. P. (2007). Sociocultural theory. B. Van Patten, J. Williams (Eds.), Theories in second language acquisition: An introduction, Lawrence Erlbaum Associates, Mahwah, NJ. International handbook of English language teaching, Springer: 693-700.

Lantolf, J. P., \& Poehner, M. E. (2014). Sociocultural theory and the pedagogical imperative in L2 education: Vygotskian praxis and the research/practice divide. Routledge.

Martin, F., \& Bolliger, D. U. (2018). Engagement matters: Student perceptions on the importance of engagement strategies in the online learning environment. Online Learning, 22(1), 205-222.

Martin, F., Sun, T., \& Westine, C. F. (2020). A systematic review of research on online teaching and learning from 2009 to 2018. Computers \& education, 159, 104009. https://doi.org/10.1016/j.compedu.2020.104009

Martin, F., \& Whitmer, J. C. (2016). Applying learning analytics to investigate timed release in online learning. Technology, Knowledge and Learning 21(1), 59-74. include the doi

Meyer, G., Adomavicius, G., Johnson, P. E., Elidrisi, M., Rush, W. A., Sperl-Hillen, J. M., \& O'Connor, P. J. (2014). A machine learning approach to improving dynamic decision making. Information Systems Research, 25(2), 239-263.

Moh'd A. H. O., \& Huwari, I. F. (2021). Patterns of Vocabulary Learners Strategies Employed by Saudi EFL Learners. Review of International Geographical Education Online 11(3), 797-807.

Mohsen, M. A., \& Shafeeq, C. (2014). EFL Teachers' Perceptions on Blackboard Applications. English Language Teaching, 7(11), 108-118.

Moore, M. G., \& Kearsley, G. (2011). Distance education: A systems view of online learning. Cengage Learning.

Narwani, A., \& Arif, M. (2008). Blackboard Adoption and Adaptation Approaches, in M. Iskander (ed.), Innovative Techniques in Instruction Technology, E-learning, Eassessment, and Education, 59-63. Springer, Netherlands. (DOI: 10.1007/978-1- 4020$8739-4)$

Norton, P., \& Hathaway, D. (2009). Exploring online learning through design and design-based research. Society for Information Technology \& Teacher Education International Conference, Association for the Advancement of Computing in Education (AACE). (pp. 1042-1049). Charleston, SC, USA.

Penuel, W. R., Abrahamson, L., \& Roschelle, J. (2006). Theorizing the transformed classroom: Sociocultural interpretation of the effects of audience response systems in higher education. In Audience response systems in higher education: Applications and cases (pp. 187-208). IGI Global. DOI: 10.4018/978-1-59140-947-2.ch013

Pusuluri, S., Mahasneh, A., \& Alsayer, B. A. M. (2017). The application of blackboard in the English courses at Al Jouf University: perceptions of students. Theory and Practice in Language Studies, 7(2), 106-111. DOI: http://dx.doi.org/10.17507/tpls.0702.03

Qizi, K. D. S. (2021). The Use Of Technology In English Language Learning. Euro-Asia Conferences.124-127 Retrieved from http://papers.euroasiaconference.com/index.php/eac/article/view/221. 
Arab World English Journal (AWEJ) 2nd Special Issue on Covid 19 Challenges January 2022

Raji, B. (2019). Significance and challenges of computer assisted education programs in the UAE: A case study of higher learning and vocational education. Education and Information Technologies, 24(1), 153-164.https://doi.org/10.1007/s10639-018-9767-6

Roddy, C., Amiet, D. L., Chung, J., Holt, C., Shaw, L., McKenzie, S., ... \& Mundy, M. E. (2017). Applying best practice online learning, teaching, and support to intensive online environments: an integrative review. Frontiers in Education, Frontiers.2.59 https://doi.org/10.3389/feduc.2017.00059

Roschelle, J., et al. (2006). Roschelle, J., \& Penuel, W. R. (2006, June). Co-design of innovations with teachers: definition and dynamics. In Proceedings of the 7th international conference on Learning sciences (pp. 606-612).

Sadeghi, B., Rahmany, R., \& Doosti, E. (2014). L2 teachers' reasons and perceptions for using or not using computer mediated communication tools in their classroom. Journal of Language Teaching and Research, 5(3), 663-673. doi:10.4304/jltr.5.3.663-673

Sharpe, R., \& Oliver, M. (2007). Designing courses for e-learning. In H. Beetham \& R. Sharpe (Eds.), Rethinking pedagogy for a digital age, Routledge: 61-71.

Shurden, S.B., Santandreu, J. \& Shurden, M.C. (2010). How student perceptions of ethics can lead to future business behavior. Journal of Legal, Ethical and Regulatory Issues 13(1), $117-127$

Ta'amneh, M. A. A. A. (2021). An Analysis of Various Vocabulary Learning Strategies Used by EFL University Students. Journal of Applied Linguistics and Language Research $8(3), 77-88$.

Thornbury, S. (2005). Beyond the sentence. Oxford: Macmillan Education.

Tyler, E. J., Hughes, J. C., Beverley, M., \& Hastings, R. P. (2015). Machine learning for holistic evaluation of scientific essays. International Conference on Artificial Intelligence in Education, Springer.

Whitmer, J. (2016). How successful students use LMS tools-confirming our hunches. Blackboard Blog.

Widdowson, H. (1994). Autonomous learner and authentic language. Autonomy in language learning, 381-394.

Yen, T.-F. T. (2020). The performance of online teaching for flipped classroom based on COVID-19 aspect. Asian Journal of Education and Social Studies, 57-64. 